\title{
Biochemical Composition of Warty Crab (Eriphia verrucosa) in the Post-reproductive Period in the Black Sea
}

\author{
Seval DERNEKBAŞI*, İsmihan KARAYÜCEL and Sedat KARAYÜCEL \\ University of Sinop, Faculty of Fisheries, Department of Aquaculture, Sinop, Turkey \\ *Corresponding author: Dr. Seval Dernekbasi, University of Sinop, Faculty of Fisheries, Department of Aquaculture, Sinop, Turkey; E-mail: sevalyaman@hotmail.com
}

Received: March 26, 2021; Accepted: April 05, 2021; Published: April 12, 2021

\begin{abstract}
In the study, changes in biochemical composition of warty crabs, Eriphia verrucosa between female and male individuals after the reproductive period were evaluated. The warty crabs used as study material were freshly obtained from fishermen after the breeding season (end of July). According to the data obtained in the study where the female and male individuals were evaluated separately, the average moisture, crude protein, crude lipid and crude ash contents in female E. verrucosa were $77.89 \%, 20.96 \%, 0.91 \%$ and $2.66 \%$, respectively. In male E. verrucosa, it was found to be $76.30 \%, 21.44 \%, 0.79 \%$ and $2.47 \%$, respectively. In the study, it was determined that the difference between male and female individuals in crude protein and crude lipid values was significant $(\mathrm{p}<0.05)$. Although the crude protein content was low in females, the crude lipid content was found to be higher. In other words, it was determined that while the protein ratio decreases in female individuals after the reproductive period, the lipid ratio increases. This suggests that the energy lost due to ovulation during the reproductive period may have been met by the accumulation of fat in the body.
\end{abstract}

Keywords: Eriphia verrucosa, Post reproductive, Biochemical

\section{Introduction}

The vast majority of crab production comes from hunting. Hunting is generally carried out with crab baskets, nets, bottom trawls, dredges and ladles, depending on the environment in which the species lives [1]. Although various parts of the body can be eaten in crabs, white meat in its pincers is most preferred. Crabs are a fishery product that finds very high value in developed countries in terms of edible meat quality and economic value. There is a crab industry in developed countries, and crabs that pass through various processing stages are produced in different products in this industry [2].

Crab meat is indicated as an important nutrient in a balanced diet because it is rich in protein, mineral substances and vitamins and low in fat [3]. Crabs contain high amounts of iron, potassium, selenium, zinc and vitamin B1, which are beneficial for human health [4]. Although sea crabs, which have become an industry loved and consumed in various countries, are among the least known fisheries in terms of human consumption in our country [5], they are consumed with pleasure and intensely by the people of the region.

However, although Eriphia verrucosa is a commercially used and fondly consumed fishery product in Mediterranean countries, it is not preferred in our country due to our traditional nutrition culture [6]. In this study, by investigating the post-reproduction biochemical composition of warty crab (E. verrucosa), which is not economically evaluated in our country but has high economic and nutritional value, and it aimed to promote the increase of the consumption and use of this species in Turkey.

\section{Materials and Methods}

Thirty female (average $62 \mathrm{~g}$ and $50 \mathrm{~cm}$ ) and male (average 85 g and $53 \mathrm{~cm}$ ) warty crabs used in the study were freshly obtained from fishermen at the end of July. The samples were transported immediately to Sinop University, Faculty of Fisheries, Feed Technology and Aquaculture laboratory in ice-filled containers. After length and weight measurements were made, the meats in the pincers were separated manually, homogenized and stored at $-80^{\circ} \mathrm{C}$ until analyzed.

All biochemical analyses in crab meats were made on a wet basis. All analyses [Dry matter (DM), crude protein (CP), crude lipid (CL), and crude ash (CA)] were performed according to the standard methods of the Association of Official Analytical Chemists [7]. Dry matter was detected by drying the samples at $105^{\circ} \mathrm{C}$ until a constant weight was achieved. Crude lipid (CL) content was determined according to the procedure of the Soxhlet method. Crude protein (CP) content was determined as total nitrogen content by the Kjeldahl method. Crude ash content was measured after samples were treated in a muffle furnace at $550^{\circ} \mathrm{C}$ for $6 \mathrm{~h}$. All analyses were performed in triplicate.

All analysis results were presented as mean values $\pm \mathrm{SE}$. AndersonDarling and Levene's tests were used for homogeneity of variances and equality of variance of groups, respectively. The differences between the results were analyzed using one-way analysis of variance (ANOVA), followed by Tukey's method for multiple comparisons. Arcsine square root transformations of percentage data were conducted for homogeneity of variances before statistical analysis. Differences were 
considered significant when $\mathrm{p}<0.05$. Statistical analysis was done by using the Minitab 17 statistical software for Windows.

\section{Results and Discussion}

In the study, it was aimed to determine the post-breeding biochemical properties of crabs. In the research, male and female crabs were taken from fishermen in July, and biochemical analyzes were made and evaluated. Proximate composition of female and male warty crabs (E. verrucosa) used in the study are given in Table 1. Changes in moisture, protein, fat and ash contents (\%) of female and male wart crabs are shown in Figure 1.

In the present study, moisture and ash contents of female and male crabs were determined as $77.89 \pm 0.12 \%, 2.66 \pm 0.09 \%$ and $76.30 \pm$ $0.07 \%, 2.47 \pm 0.17 \%$, respectively. In terms of moisture content, it was determined that the statistical difference between female and male individuals was significant $(\mathrm{p}<0.05)$, while the difference between ash contents was not statistically significant $(p>0.05)$. [4] found that warty crabs had a lower moisture content of $74.4 \%$ and ash content of $1.8 \%$ than the findings of the present study. [8] found moisture and ash contents of warty crab as $78.03 \%$ and $1.81 \%$, respectively, in the comparative analysis of biochemical compositions of warty crabs, blue crabs (Callinectes sapidus) and crabs (Cancer pagurus). In terms of moisture, although they show similarity with the present study, reported that the ash content was lower. [9] reported warty crabs moisture and ash contents as $76.13 \pm 0.04 \%$ and $2.35 \pm 0.01 \%$, respectively, and similar results were obtained. [10] determined the moisture and ash content of female and male warty crabs as $75.44 \%$ $2.08 \%$ and $75.44 \%-3.41 \%$, respectively. While showing similarities

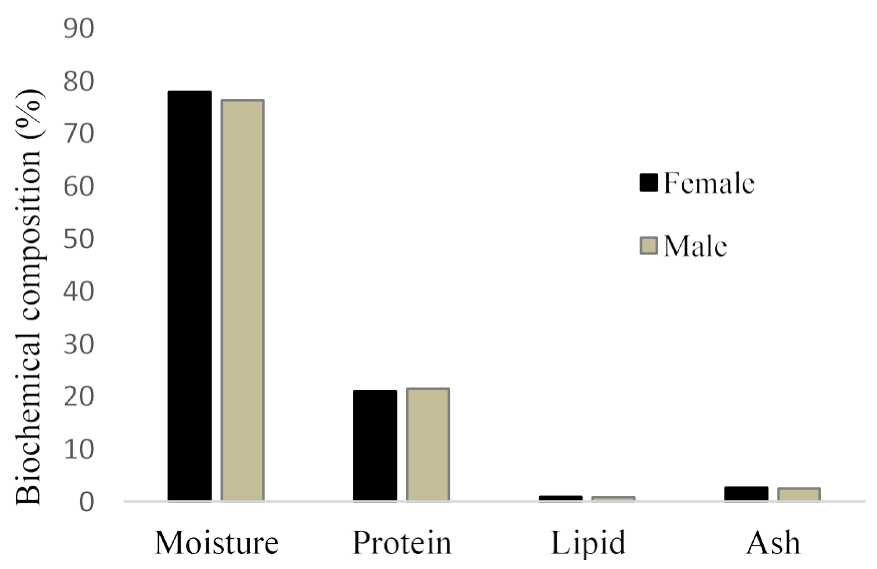

Figure 1: Changes in moisture, protein, fat and ash contents (\%) of female and male warty crabs.

Table 1: Proximate composition (\%) of female and male warty crabs (E. verrucosa) (wet weight).

\begin{tabular}{|l|c|c|}
\hline & Female & Male \\
\hline Moisture (\%) & $77.89 \pm 0.12^{\mathrm{a}}$ & $76.30 \pm 0.07^{\mathrm{b}}$ \\
\hline Protein (\%) & $20.96 \pm 0.53^{\mathrm{b}}$ & $21.44 \pm 0.31^{\mathrm{a}}$ \\
\hline Lipid (\%) & $0.91 \pm 0.13^{\mathrm{a}}$ & $0.79 \pm 0.01^{\mathrm{b}}$ \\
\hline Ash (\%) & $2.66 \pm 0.09^{\mathrm{a}}$ & $2.47 \pm 0.17^{\mathrm{a}}$ \\
\hline
\end{tabular}

Data are reported as mean \pm standard errors of three replicate (3). Rows values with the same superscript or no superscript are not significantly different $(\mathrm{p}>0.05)$. with the present study in terms of moisture content, it was determined that ash content was lower in female individuals and higher in male individuals. Again, [11] reported that female and male warty crabs determined the moisture and ash content as $74.30 \%-2.00 \%$ and $75.47 \%-1.85 \%$, respectively. [5] reported that in their study comparing the nutritional composition between male and female members of blue crab (Callinectes sapidus) and sand crab (Portunus pelagicus), moisture and ash contents in female and male individuals of blue and sand crabs was $82.03 \%-2.20 \%$ and $80.35 \%-1.68 \%$, and $80.13 \%-2.66 \%$ and $79.84 \%-2.36 \%$, respectively.

In the present study, the protein contents of female and male crabs were determined as $20.96 \%$, and $21.44 \%$, respectively. In terms of protein content, the difference between male and female individuals was determined to be statistically significant $(\mathrm{p}<0.05)$. [10] reported that they determined the protein contents in female and male wart crabs as $21.29 \%$ and $20.80 \%$, respectively. [9] reported that the amount of crude protein was $19.66 \pm 0.02 \mathrm{~g} / 100 \mathrm{~g}$ in their studies to determine the nutritional composition of 20 warty crabs (154.91 g), regardless of gender. [6] determined the protein content as $17.12 \%$ in their study in which they determined the close composition of wart crab during cold storage. [4] reported the crude protein amount as 21.30 $\pm 0.01 \%$ in July in a study they conducted on 113 crabs in order to determine the biochemical compositions of the crabs they obtained from the Karakum region of Sinop during the reproductive period. It has been determined that the findings of this study are consistent with the findings of the present study. [11] reported that female and male warty crabs determined the protein contents as $22.45 \%$ and $21.40 \%$, respectively. When the values they obtained were compared with the findings of our study, it was determined that the amount of crude protein was high. This difference is thought to be due to the difference in the research area and the number of samples. [5] reported that the protein contents of male and female blue and sand crabs were $14.26 \%$ $16.81 \%$ and $15.83 \%-17.55 \%$, respectively. The difference between the current study and the study is thought to be due to differences in the research region and species.

In the present study, the crude lipid content of female and male crabs was determined as $0.91 \%$ and $0.79 \%$, respectively. In terms of lipid content, the difference between female and male individuals was determined to be statistically significant $(\mathrm{p}<0.05)$. Ayas and Özoğul [11] reported that female and male warty crabs determined the lipid contents as $0.96 \%$ and $1.11 \%$, respectively. Durmus et al. [10] reported that they determined the lipid contents in female and male wart crabs as $0.95 \%$ and $0.92 \%$, respectively. Kaya et al. [9] the amount of crude oil $0.66 \pm 0.01 \mathrm{~g} / 100 \mathrm{~g}$, Demirbaş et al. [4] determined the amount of crude lipid as $0.40 \pm 0.01 \%$ in July. It was determined that the lipid contents determined in both studies were lower than in the current study. It is thought that the difference determined between the current study and the study of Demirbaş et al. [4] may be related to the method of obtaining the material to be analyzed. Türeli et al. [5] reported that the protein contents of male and female blue and sand crabs were $\% 1.51-\% 1.16$ and $\% 1.38-\% 1.33$, respectively. The difference between the current study and the study is thought to be due to differences in the research region and species. 


\section{Conclusion}

As a result, these creatures, which have an important place in the ecosystem and are an important food source due to their high protein value and low fat ratio, need to be investigated more in today's world where food sources are decreasing day by day and alternative food sources are tried to be created. Efforts should be made to introduce and spread these creatures, which are consumed only in coastal areas in our country, to consumers in every region as food. In addition, basic research should be done about our natural resources in terms of sustainable fisheries and these studies should be made widespread.

\section{References}

1. Selimoğlu AŞ (1997) Trabzon kıyı sularında bulunan yengeç türlerinden Liocarcinus vernalis (Risso, 1816) ve Pachygrapsus marmoratus (Fabricius, 1787)'un bazı biyo-ekolojik özelliklerinin belirlenmesi. Yüksek Lisans Tezi, Karadeniz Teknik Üniversitesi, Fen Bilimleri Enstitüsü, Trabzon.

2. Paul A, Haefner JR (1985) The biology and eploitation of crabs. The Biology of Crustacea 10: 111-163.

3. Erkan M, Balkıs H, Kurun A, Tunalı Y (2008) Seasonal variations in the ovary and testis of Eriphia verrucosa (Forskal, 1775) (Crustacea: Decapoda) from Karaburun, SW Black Sea. Pakistan J. Zool 40: 217-221.
4. Demirbaş A, Eyüboğlu B, Baki B, Sarıipek M (2013) Eriphia verrucosa (Forsskal, 1775) Yengecinin Üreme Dönemi Biyokimyasal Özelliklerinin Belirlenmesi. Yunus Araștırma Bülteni 4: 15-19.

5. Türeli C, Celik M, Erdem Ü (2000) İskenderun Körfezi'ndeki mavi yengeç (Callinectes sapidus Rathbun, 1896) ve kum yengeçlerin (Portunus pelagicus Linne, 1758)'de et kompozisyonu ile veriminin araştırılması. Türk J. Vet. Anim. Sci 24: 195-203.

6. Altinelataman C, Dincer T (2007) Proximate composition and freshness parameters in refrigerator stored warty crab meat (Eriphia verrucosa Forskal, 1775). Archiv für Lebensmittelhygiene 58: 132-135.

7. AOAC (1995) Animal Feed. W. Horwitz (Ed.). Official Methods of Analysis of the Association of Analytical Chemists, 13th Edition 7: 125. USA.

8. Zotto M, Del Coco L, De Pascali SA, Migoni D, Vizzini S, et al. (2016) Comparative analysis of the proximate and elemental composition of the blue crab Callinectes sapidus, the warty crab Eriphia verrucosa, and the edible crab Cancer pagurus. Heliyon e00075.

9. Kaya Y, Turan H, Erdem ME (2009) Determination of nutritional quality of warty crab (Eriphia verrucosa Forsskal, 1775). Journal of Animal and Veterinary Advances 8: $120-124$.

10. Durmus M, Ayas D, Aydin M, Kosker AR, Ucar Y, et al. (2018) The effects of sex and seasonality on the metal levels of warty crab (Eriphia verrucosa) in the Black Sea. Journal of Aquatic Food Product Technology 749-758.

11. Ayas D, Özoğul Y (2011) The chemical composition of carapace meat of sexually mature blue crab (Callinectes sapidus, Rathbun 1896) in the Mersin Bay. Journal of FisheriesSciences.com 5: 262-269. 